\title{
The delayed effects of flooding a residential building - case study
}

\author{
Grzegorz Straż ${ }^{1, *}$ \\ ${ }^{1}$ Rzeszow University of Technology, Faculty of Civil and Environmental Engineering and \\ Architecture, Department of Geodesy and Geotechnics, 35-959 Rzeszów, Poznańska 2, Poland
}

\begin{abstract}
The work describes the case of a single-family residential building, which suffered a breakdown due to flooding. Flooded water in the nearby watercourse, did not reach the building directly, but in its vicinity, but raised to a very high level the local groundwater table, which reached locally, even above ground level. This condition was maintained over a longer period of time, causing the soil moisture to rise, and thus its geotechnical parameters deteriorated. The consequence of this, the building underwent an uncontrolled and uneven settlement, which was accompanied by the formation of cracks on the walls. The effects of failure were presented and an attempt was made to identify possible causes of failure. Own study of the substrate was carried out in "in situ" conditions and verification of laboratory tests, and their results are presented on relevant charts and tables.
\end{abstract}

\section{Introduction}

Hydrological floods due to the genesis can be divided into four groups: rain (type $O$ ), snowmelt (type R), winter (type Z) and storm (type S). It is believed that in Poland the main cause of flooding is rainfall of varying intensity and duration, causing summer and winter rainfalls, which may lead to the occurrence of watercourses from the troughs and, consequently, to cause a natural disaster. The year 2010 was particularly dangerous in this respect, as the exceptionally intense and long-lasting flood waves swept through the Polish territory several times, bringing huge losses of a material, economic and social nature. Podkarpackie Province, whose area is located in the Upper Vistula basin with a welldeveloped hydrogry network, also suffered as a result of the direct impact of the element. The areas of the Podkarpackie Province directly affected by flooding are presented in Figure 1.

\footnotetext{
*Corresponding author: gstraz@prz.edu.pl
} 


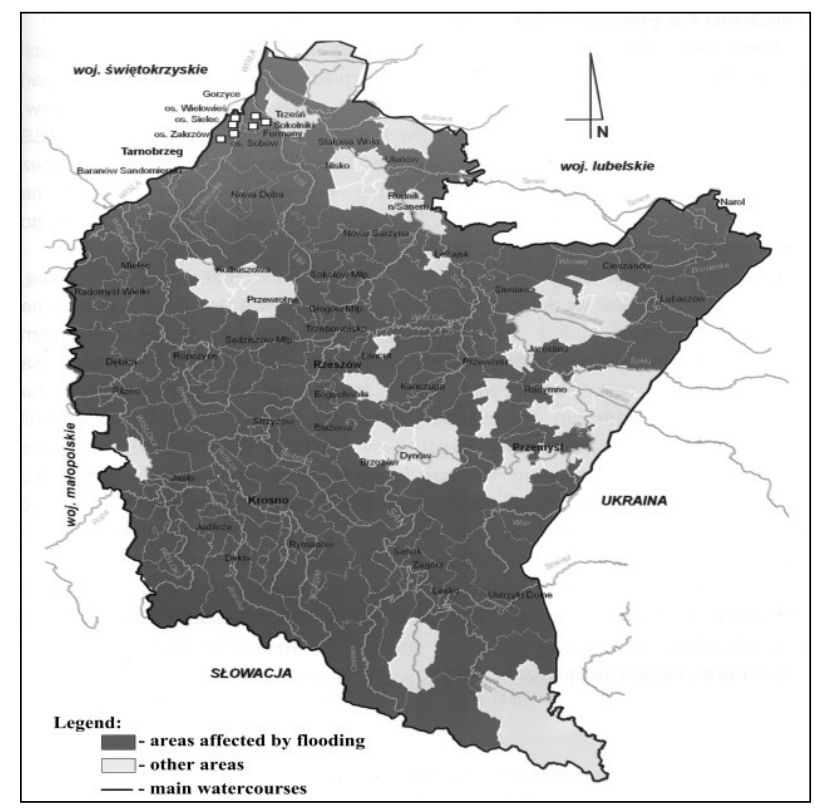

Fig. 1. Distribution of areas suffered as a result flooding in May-June 2010 in the Podkarpackie Province [1].

The effects of typical (hydrological) floods visible immediately after their resignation are not the only ones. It happens that they are accompanied by other effects delayed in time, being a consequence of another type of floods, so-called hydrogeological, which may lead to a change in soil-water relations. In the case of major changes, they cause difficulties, prevent the use of construction objects, engineering structures and may even lead to the exclusion of significant development areas from use. The probability of their occurrence is greatest in areas located along large river valleys, when the water rises to catastrophic levels, areas with complex geological structure, glacitectonically disturbed and man-made morphology. Hydrogeological floods can be extremely dangerous, because in contrast to typical hydrological floods, they appear unnoticed, develop slowly, can last for a very long period of time (even years) and give way for a long time. Often the reasons for their formation are ambiguous and difficult to determine [2]. The paper presents a case study of a building failure, the occurrence of which is related directly and indirectly to locally occurring flooding.

\section{Effects of a failure - case report}

\subsection{The site characteristics and geological setting}

Study area is located in south-eastern Poland in the central part of the Podkarpackie Voivodeship, a short distance from the Rzeszów city. Physico-geographical region is the Subcarpathian Urstromtal is an early-quaternary erosional decline, located at 180-200 m above sea level as part Macroregion Sandomierz Basin. Towards the east, the Wisłok River meanders the flat plain, which has changed the trough and has left many depressions and oxbow lakes. There are a few terraced steps on the slopes of the ice-marginal valley, which are the remains of the glaciation recession. Geologically, the area is located mainly within the Carpathian Foredeep. The valley floor of today's is filled mostly late glacial and Holocene sediments [3]. 


\subsection{Description of the study object}

The case concerns a residential building, single-family house, ground floor, basement, with a non-usable, freestanding substructure, operated since the mid-1990s, with a usable area of approx. $250 \mathrm{~m}^{2}$. Construction walls with a building thickness of approx. $0.4 \mathrm{~m}$ were made as layered: silicat, polystyrene and cellular concrete, and partition walls of various thicknesses from silicates. All ceilings were made as monolithic reinforced concrete, and the roof was covered with sheet metal. The building was founded at a depth of approx. $1.5 \mathrm{~m}$ under ground level, directly on reinforced concrete foundation walls with a width of approx. $0.4 \mathrm{~m}$, which were secured by making water-resistant, external vertical insulation. Genealogically, the terrain is flat with a minimal slope towards a small watercourse passing by several dozen meters, which is a tributary of the Wisłok River.

\subsection{Assessment of effects of a failure}

In the mid-1980s, the flood affected the area twice. As a result of backwater in nearby watercourses, the water level was raised to a level almost equal to the level of the area next to the building, because the water get at to study area a few meters from the building and stayed some days. The building did not directly flood, but indirectly through the elevated level of the groundwater table, which flooded the cellars to a depth of a few $\mathrm{cm}$. From the user's account it appears that the first building cracks appeared before flooding, around 2009, mainly in the south and west wall, but they were not large or progressive, so no remedial measures were taken.Visual inspection showed damage that water got into the basement through connection of the walls with the floor and probably direcly infiltration through the floor. Other damages, in addition to moistening basement walls, have not been observed. After the water subsided, the cellars were drained and no new damage to the walls and floor was found. Unfortunately, after few years it turned out that on the inside and outside walls, cracks appeared on all of the tiers, testifying to the progressive, non-uniform settlement of the building. Due to the fact that the building was stable for more than 15 years, one can assume that one of the reasons for the failure was the exceptionally high level of groundwater table after flooding, which led to a significant deterioration of soil conditions.

Damage to external walls was mainly observed in the form of "stair step" cracks in northwest corner and horizontal cracks between the windows at the height of the lintel on the south facade. Fine cracks appeard on wall of west facade. Vertical foundation cracks about $3 \mathrm{~mm}$ emerged mainly in corners of cellar and at the level of horizontal dump insulation they changed direction to parallel to it. Inside the building on the ground floor level, scratches occurred in a different arrangement on all walls. The most serious were the oblique and "stair step" cracks features going through almost the entire wall and changing direction to levels just below the ceiling. Vertical cracks from window corners to floors and independent horizontal at different heights from the floor were also observed. The width of the cracks on the interior walls of the building generally did not exceed $2 \mathrm{~mm}$. Due to the wide range and size of the cracks, the investor has taken steps to assemble a simple crack monitoring installation in the form of glass strips glued by resin to the wall and gypsum seals. Observations have shown that the opening of individual fractures is progressive. About 50 seals have been installed from which $70 \%$ were damaged. New small cracks and cracks were also observed. This has confirmed that the settlement process of the building has been started and continues. Exemplary cracking of walls of cellar and first floor shows Figure 2 and 3. 

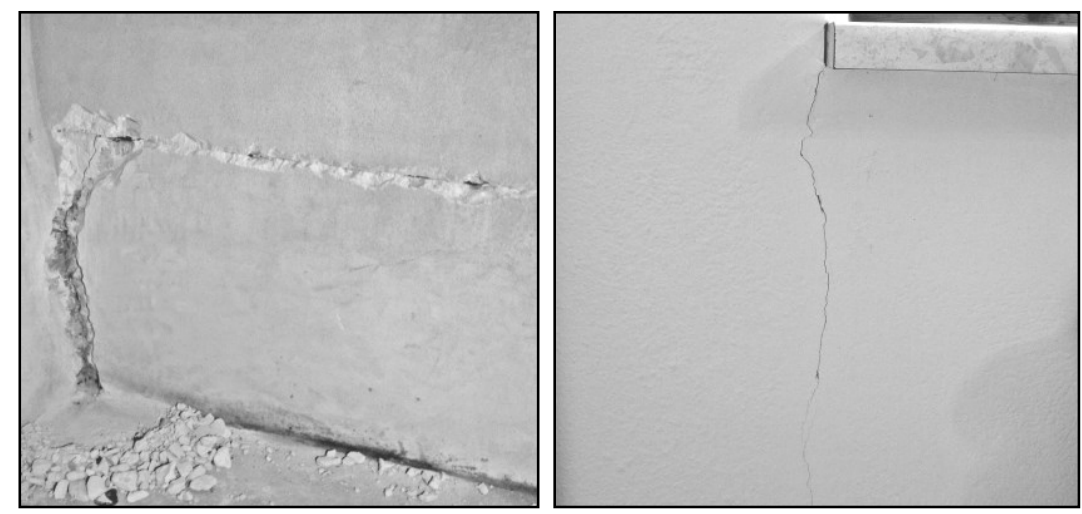

Fig. 2. Exemplary cracking of walls of cellar.
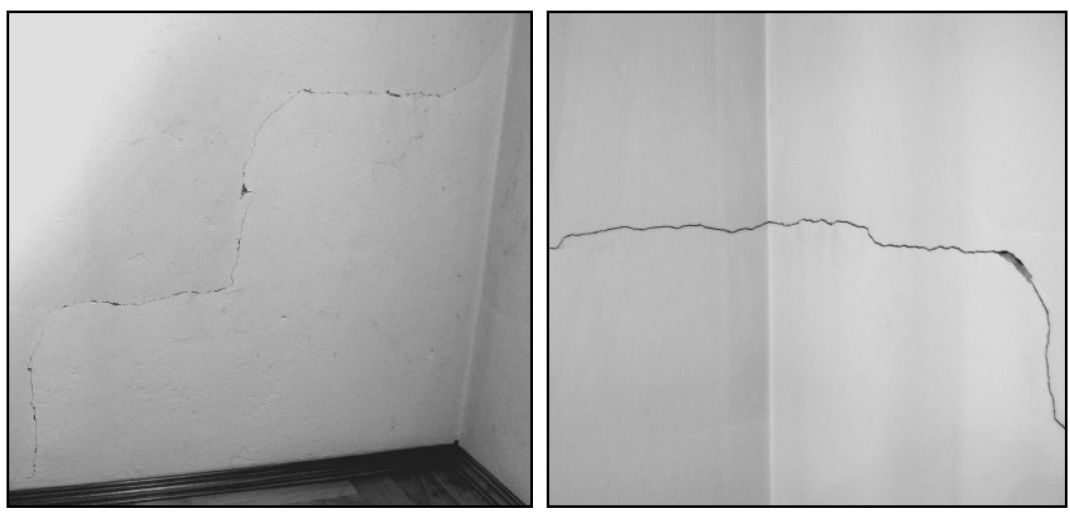

Fig. 3. Exemplary cracking of walls of first floor.

\section{Ground testing results}

\subsection{Methods used in the evaluation of the subsoil}

Assessment of subsoil was made on the basis of laboratory and in situ tests. In the immediate vicinity of the building which was damaged, four boreholes were drilled up to approx. $6 \mathrm{~m}$ depth, from which soil samples with undisturbed structure were collected for selected laboratory tests. At the same time, next to the boreholes, a soil test was carried out using a dynamic penetrometer DPL (Dynamic Probing Penetrometer) [4]. The ground conditions and soil index properties soil was determined on base results of lab researches samples collection from Boreholes. Samples with undisturbed end disturbed structure were obtained and used to identification, macroscopic analysis and laboratory tests. The orientation of the building, the location of research Boreholes and dynamic sounding points shows Figure 4. 


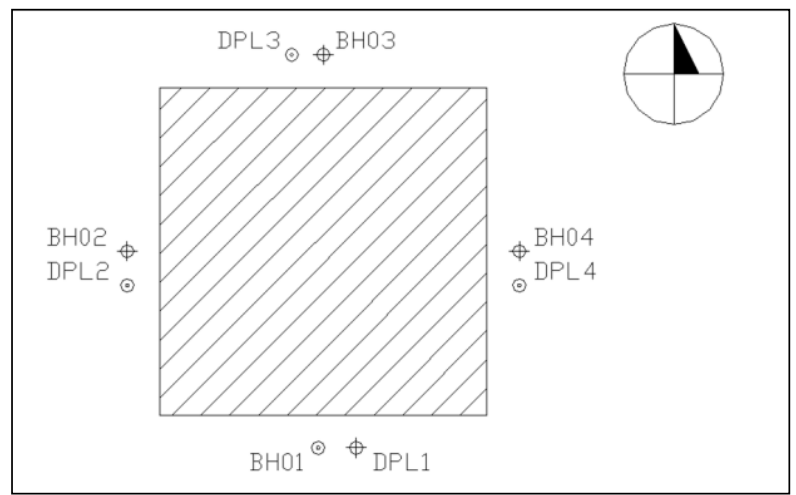

Fig. 4. The scheme of locations of Boreholes and DPL tests points at study case.

\subsection{Identification, classification and parameters of soils at study case}

In laboratory conditions, tests were carried out to identify local soil, its classification and determine the leading parameters in accordance with the standard guidelines [5-8]. Macroscopic analyses were performed as well as natural water content, organic matter content, consistency and consistency index.

\subsection{In situ testing procedures}

\subsubsection{Determination of consistency from in situ tests}

The accurate methods for determining the states or consistency of the soil are laboratory methods, whereas they require obtaining and delivering the appropriate quality of soil samples to the laboratory, which is especially difficult in the case of organic soils, and often even impossible [9]. Whereas for a precise diagnosis of the substrate used for this purpose the Dynamic Probing Light which is a type of penetrometer that is economical in operation, easy and quick to use, which is essentially used for testing cohesiveless soils. Procedures have also been developed that allow for careful estimation of cohesion, consistency or dynamic point resistance [4] of cohesive soils, including organic ones. Researches in this heartbeat were carried out by Frankowski [10], Rybicki and Krokoszyński [11] or Straż [12], who showed a correlation between the results of different types of soundings, comparing the results of alternative research.

For the purpose of this work, the consistency of the soil was determined by the method proposed by Frankowski, comparing the work of selected dynamic penetrometers with the use of dimensionless coefficient $\beta$ formulated by Teferra [10]:

$$
\beta=A_{\mathrm{SPT}} / A_{\mathrm{DPL}}
$$

where:

$A_{\mathrm{SPT}}$ - work carried out on the reference unit of the SPT

$A_{\mathrm{DPL}}$ - work carried out on the reference unit of the DPL.

It should be noted that this method is an additional method whose results should be verified by classical laboratory methods. 


\subsubsection{Dynamic point resistance from dynamic probing}

Basic parameters for dynamic probe type DPL shows Table 1. Dynamic point resistance of soil [4] calculated according to the transformation of Dutch formula from Annex D Polish Standard [13]:

$$
q_{d}=\frac{m}{m+m^{\prime}} r_{d}=\frac{m}{m+m^{\prime}} \frac{m g h}{A e}
$$

where:

$m$ - mass of the hammer,

$m$ '- total mass of the extension rods, the anvil and guiding rod,

$r_{d}$ - resistance values,

$g$ - acceleration due to gravity,

$h$ - height of fall of the hammer

$A$ - nominal base area of the cone,

$e$-average penetration, in $\mathrm{m}$ per blow.

Table 1. Basic parameters for dynamic probe DPL.

\begin{tabular}{|c|c|c|c|c|c|}
\hline $\begin{array}{c}\text { Hammer } \\
\text { mass }\end{array}$ & $\begin{array}{c}\text { Falling } \\
\text { height }\end{array}$ & $\begin{array}{c}\text { Acceleration } \\
\text { due to gravity }\end{array}$ & $\begin{array}{c}\text { Nominal base } \\
\text { area of the } \\
\text { cone }\end{array}$ & $\begin{array}{c}\text { Cavity of } \\
\text { the cone }\end{array}$ & $\begin{array}{c}\text { Drive rod, anvil } \\
\text { and hammer } \\
\text { guide mass }\end{array}$ \\
\hline $\mathbf{m}[\mathbf{k g}]$ & $\mathbf{h}[\mathbf{m}]$ & $\mathbf{g}[\mathbf{N} / \mathbf{k g}]$ & $\mathbf{A}\left[\mathbf{m}^{2}\right]$ & $\mathbf{e}[\mathbf{m}]$ & $\mathbf{m}$ ' $[\mathbf{k g}]$ \\
\hline $10 \pm 0.1$ & $0.5 \pm 0.01$ & 9.81 & 0.001 & $0.1 / \mathrm{N}_{10}$ & 9.0 \\
\hline
\end{tabular}

\subsection{Results of determinations and tests}

Laboratory tests have shown that mainly silty soils containing various amounts of organic matter content are found in the subsoil. Tests for determination of soil organic matter (SOM) in accordance of Polish Standard were carried out [8]. However, the identification of land based on organic matter content is not explicit because currently there are different classification systems in Poland, which the author pointed out in another paper [14]. Classification of soils containing organic matter according to the commonly used for engineering purposes of the Polish Standard [8] is distinguished by: humus soils $(2<\mathrm{SOM}<5 \%)$, warps, muds $(5<\mathrm{SOM}<30 \%)$ and peats $(\mathrm{SOM}>30 \%)$. The newest classification standard [6,7] has been applied to: low-organic $(2<\mathrm{SOM}<6 \%)$, mediumorganic $(2<\mathrm{SOM}<6 \%)$ and high-organic $(\mathrm{SOM}>30 \%)$, without connection to the soil name. The exemplary cross-section under corners of the building can be seen in Figure 5 and 6 . 


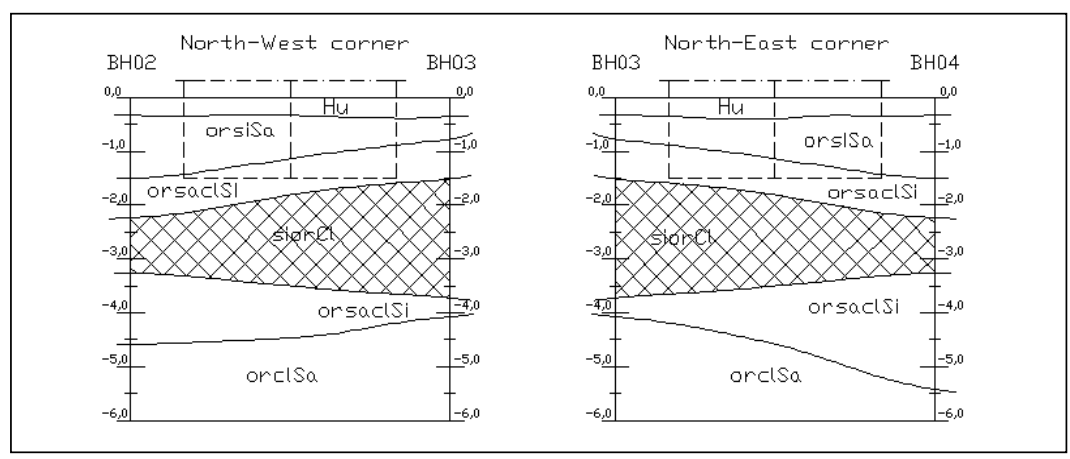

Fig. 5. The exemplary cross-section showing soils layers under N-W and N-E corners of building.

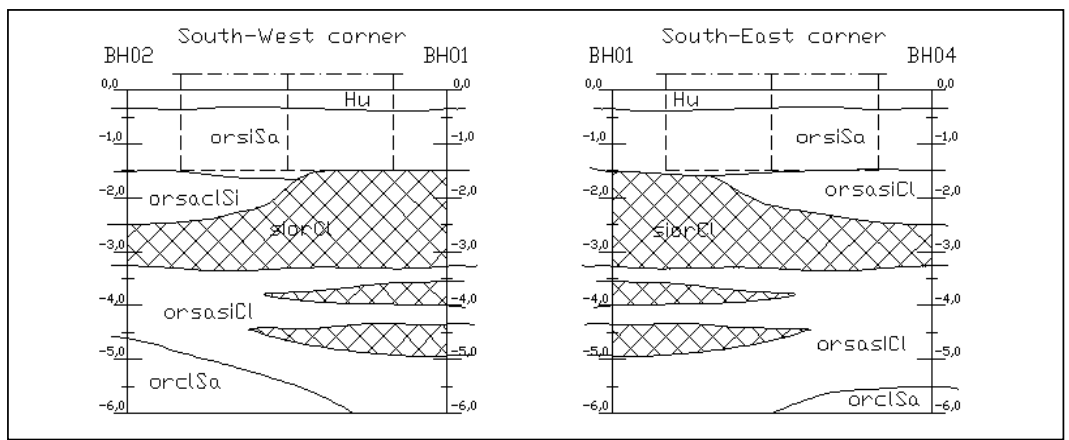

Fig. 6. The exemplary cross-section showing soils layers under S-W and S-E corners of building.

The weakest layer composed of soils with the highest content of organic parts siorCl (silty organic clay - warp) clearly appears on the cross-sections, which has the shape of a lens positioned in the north-south direction. Its largest thickness $(1.75-2.25 \mathrm{~m})$ was observed on the Borehole BH01-BH03. Additionally, within the Borehole BH01, two further, smaller lenses with a thickness of approx. 0.5 to $0.75 \mathrm{~m}$ were located. In the east and west directions of the BH01-BH03 line, the lens reduces the thickness to approx. $0.75 \mathrm{~m}$ next to the BH02 and $\mathrm{BH} 04$ bores. Layers of soft soil are mainly surrounded by silty soils containing a small addition of organic parts (orsiSa - silty sand with organic substance, orsasiCl - silty clay with sand and organic substance, orclSa - clayey sand with organic substance). During the measurements, the location of the groundwater table level was set at a depth of 2.25 to $3.45 \mathrm{~m}$ below soil level. The soil-water conditions were extremely complicated and the building could have been subject to uneven settlement from the very beginning. Laboratory tests have shown that the weakest layer is siorCl with consistency from very soft plastic to plastic. Detailed information on the value of selected geotechnical parameters of the separated layers is presented in Table 2 . 
Table 2. Soil profile and range of basic parameters value.

\begin{tabular}{|c|c|c|c|c|c|c|c|c|}
\hline \multirow[b]{2}{*}{ 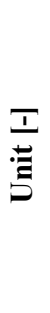 } & \multirow[b]{2}{*}{$\begin{array}{l}I \\
\overline{0} \\
0 \\
0 \\
0 \\
0 \\
0 \\
0\end{array}$} & \multirow{2}{*}{ 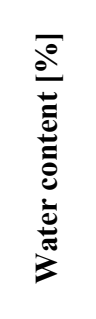 } & \multirow{2}{*}{ 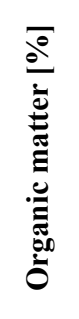 } & \multirow{2}{*}{ 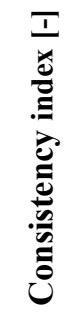 } & \multirow[b]{2}{*}{ 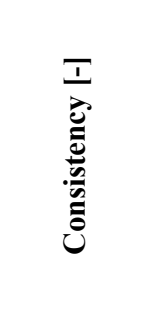 } & \multicolumn{3}{|c|}{ Dynamic Probing } \\
\hline & & & & & & 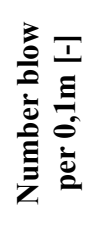 & 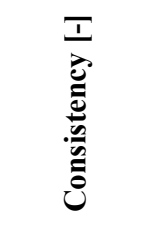 & 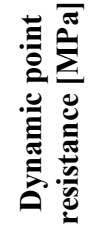 \\
\hline 1 & Humus & - & - & - & - & - & - & - \\
\hline 2 & orsiSa & $\begin{array}{l}18.84- \\
23.16\end{array}$ & $\begin{array}{c}2.19- \\
4.44\end{array}$ & $\begin{array}{c}0.67- \\
0.75\end{array}$ & Firm & $8-11$ & Firm & $\begin{array}{l}2.065- \\
2.841\end{array}$ \\
\hline 3 & orsaclSi & $\begin{array}{l}20.25- \\
29.51\end{array}$ & $\begin{array}{c}2.42- \\
4.76\end{array}$ & $\begin{array}{c}0.67- \\
0.88\end{array}$ & Firm/Stiff & $9-13$ & Firm/Stiff & $\begin{array}{c}2.323- \\
3.356\end{array}$ \\
\hline 4 & siorCl & $\begin{array}{c}33.96- \\
45.61\end{array}$ & $\begin{array}{l}5.08- \\
9.92\end{array}$ & $\begin{array}{l}0.24- \\
0.72\end{array}$ & $\begin{array}{l}\text { Very Soft } \\
\text { /Soft/Firm }\end{array}$ & $4-8$ & $\begin{array}{l}\text { Very Soft } \\
\text { /Soft/Firm }\end{array}$ & $\begin{array}{l}1.033- \\
2.065\end{array}$ \\
\hline 5 & orclSa & $\begin{array}{l}22.64- \\
24.65\end{array}$ & $\begin{array}{c}2.59- \\
4.61\end{array}$ & $\begin{array}{c}0.84- \\
0.88\end{array}$ & Stiff & $12-17$ & Firm & $\begin{array}{l}3.098- \\
4.389\end{array}$ \\
\hline
\end{tabular}

Although the consistency index isn't a typical parameter characterizing organic soils due to the lack of a suitable one, it was used to estimate ground consistency, based on consistency limits, identifications of soils and comparative purposes [7]. All the local soils are organic soils of heterogeneous structure which results in significant discrepancies in their parameters even within one geotechnical layer.

\section{Analysis of failure causes}

The analysis of the reasons for the failure of the building was based on the results of the building inspection, available archival and literature materials, information from the inhabitants and the results of research of subsoil. It was found that there are several likely causes that could have occurred together or separately. It seems that the main reason that actived the sequence of cause and effect was flooding the area several times nearby the described object. Floodwater directly didn't cause great damage to the building, while maintaining for a longer period of time, caused the groundwater table to rise to an exceptionally high level.

Beyond the information provided by local residents it turns out that a few years before the first flooding a short distance from the building combined sewerage system was made in a trench with a depth of up $5 \mathrm{~m}$. It was not possible to reach archival materials about the applied made ground, its homogeneity or method of laying in the excavation. Due to the fact that it is a filled soil, its filtration parameters could theoretically be worse than the parameters of the virgin soils. It is possible, therefore, that drainage facilitates the migration of water when the level of flooded water in the river has reached the bottom of the excavation. The local subsoil is characterized by a layered structure, which, combined with sandy interbedding, creates an excellent environment for the formation of uncontrolled, privileged filtration routes. Hence, the water could reach deep into the area and soils before physically flooding the area, causing an invisible but dangerous hydrogeological flood that changed local soil-water conditions. As a result, soil moisture increased, its condition deteriorated and the bearing capacity of the subsoil decreased. 
In addition, lab and in situ researches have shown that the subsoil were mainly organic soils, requires special consideration, which, due to their low bearing capacity and high compressibility are called soft soils, and the determination of their geotechnical parameters is extremely complicated and labour-absorbed [9, 15-17]. The geotechnical layers separated in the subsoil were characterized by variability in the organic matter content (from $2.19 \%$ to $9.92 \%$ ), due to which they were to varying degrees susceptible to changes in moisture and consequently, to the true values of geotechnical parameters. Additionally, these layers were characterized by a variable thickness, which in the case of the softest ( in the range from 0.75 to $2.25 \mathrm{~m}$. Such significant differences could generate different deformations and, as a result, uneven settlement of the building-laden subsoil.

All the factors cause that in this case there were complicated geotechnical conditions, which nowadays would require the preparation of specialist geotechnical documentation. Probably at the design stage the subsoil wasn't precisely recognized. Unfortunately, because this cannot'be referred directly to the conditions, when the building was built, due to the fact that it hasn't saved geotechnical documentation from the area.

The conducted analysis confirmed that in the case described the cause of multi-factor failure and the impact of individual factors are difficult to determine.

\section{Conclusions}

The conducted analysis confirmed that in the case described the cause of multi-factor failure and the impact of individual factors difficult to determine. Destructive processes were caused by multiple local floods, causing unfavorable changes, as well as complicated soil and water conditions. The human factor has also disappointed, since the excavation of the combined sewerage system has cut various geotechnical layers on a considerable length, which probably facilitated the filtration of water into the depth of the area and this could have changed its morphology. Additionally, at the stage of building design, the subsoil hasn't been precisely recognized, as the number of organic soils requiring special attention has not been taken into account, and this has not allowed proper selection of foundations and building structure. In general, it should be stated that in areas where flooding may occur, extremely unpredictable hydrogeological conditions are to be expected. It should also be not forgotten that changing the level of groundwater causes a change in the state of stress in the ground, generating additional settlements. Therefore, only in the case when the location of facilities in this area is absolutely necessary, buildings should be designed without basements. Without the doubt, it can be stated as well that the proper selection of the foundation and determination of reliable geotechnical parameters is always the key to the correct selection of the type and size of the foundation. Securing the subsoil on which the building structure is located before the hydrological flood, as well as hydrogeological flooding is difficult, expensive and ineffective. 


\section{References}

1. Joint Publication: E.J. Lipińska, et al., Powódź 2010 - przyczyny i skutki (Biblioteka Monitoringu Środowiska, Rzeszów, 2011) [in Polish]

2. M. Dankowski, I. Wrobel, Ochrona Przed Korozją, 10s/A/2003, pp. 42-49 (2003) [in Polish]

3. Joint Publication: Objaśnienia do mapy geośrodowiskowej Polski 1:50 000, (Państwowy Instytut Geologiczny, Warszawa, 2007) [in Polish]

4. EN ISO 22476-2:2005, Geotechnical investigation and testing - Field testing - Part 2: Dynamic probing

5. EN 1997-2: 2007, Eurocode 7 - Geotechnical design - Part 2: Ground investigation and testing

6. PN-EN ISO 14688-1:2018, Geotechnical investigation and testing — Identification and classification of soil - Part 1: Identification and description

7. PN-EN ISO 14688-2:2018, Geotechnical investigation and testing - Identification and classification of soil - Part 2: Principles for a classification

8. PN-B-04481:1998, Building soils - Research of soil samples [in Polish]

9. $\mathrm{G}$ Straż, $O$ niektórych problemach zwiąanych $z$ określaniem parametrów geotechnicznych rzeszowskich gruntów organicznych [in:] Badania i analizy wybranych zagadnień z budownictwa (Wydawnictwo Politechniki Śląskiej, Gliwice, pp. 143-150, 2011) [in Polish]

10. A Frankowski, Interpretcja wyników sondowań dynamicznych i badań presjmetrycznych (Nowoczesne Metody Badań Gruntów, Sympozjum ITB, 2003) [in Polish]

11. S. Rybicki, P. Krotoszyński, Biuletyn P.I.G., 446, pp. 397-406 (2011) [in Polish]

12. G. Straż, E3S Web of Conferences, 49, 00109 (2018)

13. PN-B-04452:2002. Geotechnics. Field tests (2002)

14. G. Straż, SR - E\&ES, 27 (2), pp. 227-235 (2018) [in Polish]

15. G. Nguyen, MATEC Web of Conferences, 196, 03024 (2018)

16. G. Straż, Przegląd Geologiczny, 64 (11), pp. 918-924 (2016) [in Polish]

17. G. Straż, Parametry wytrzymałościowe rzeszowskich namułów i torfów (Oficyna Wydawnicza Politechniki Rzeszowskiej, Rzeszów, 2011) [in Polish] 